Nigerian Journal of Environmental Sciences and Technology (NIJEST)

www.nijest.com

ISSN (Print): 2616-051X ｜ＩSSN (electronic): 2616-0501

Vol 3, No. 1 March 2019, pp 105 - 111

\title{
Elephant Grass (Pennisetum Purpureum) Mediated Phytoremediation of Crude Oil-Contaminated Soil
}

\author{
Bobor L. O. ${ }^{1, *}$ and Omosefe B. E. ${ }^{1}$ \\ ${ }^{1}$ Department of Civil Engineering, University of Benin, Benin City, Edo State, Nigeria
}

Corresponding Author: *lulu.akhigbe@ uniben.edu

\begin{abstract}
Phytoremediation is an economic and environmentally friendly method for the remediation of hazardous crude oil contaminated soils. In this study, phytoremediation of crude oil contaminated soils by elephant grass (pennisetum purpureum) was investigated over a 40-day period. Grass clumps were harvested and transplanted into plastic buckets filled with $1 \mathrm{~kg}$ of soil contaminated with $30 \mathrm{ml}$ and $40 \mathrm{ml}$ of crude oil and an uncontaminated control sample. An additional control sample was contaminated with $30 \mathrm{ml}$ of crude oil with no elephant grass. The samples were analyzed periodically for changes in $\mathrm{pH}$, total hydrocarbon content, total viable bacterial count, and total fungal count. The $\mathrm{pH}$ of the soil samples generally ranged from 5.26 to 7.85. After 40 days of treatment, the total hydrocarbon content decreased from $320 \mathrm{mg} / \mathrm{kg}$ to $38 \mathrm{mg} / \mathrm{kg}$ and from $590 \mathrm{mg} / \mathrm{kg}$ to $46 \mathrm{mg} / \mathrm{kg}$ in samples contaminated with $30 \mathrm{ml}$ and $40 \mathrm{ml}$ of crude oil respectively. Plant growth was uninhibited in contaminated and control samples as the heights increased by $34.5-42.8 \mathrm{~cm}$. The results of the study further demonstrate the phytoremediation capabilities and tolerance of elephant grass in crude-oil contaminated microcosms.
\end{abstract}

Keywords: Phytoremediation, Elephant grass, Crude oil, Hydrocarbon, Contaminated soil

\subsection{Introduction}

In oil-producing developing countries, environmental degradation is a major problem due to accidental crude oil spillages resulting in the pollution of vast amounts of agricultural land and aquatic systems (Ugochukwu and Ertel, 2008). Adverse effects of crude oil contamination include, loss of fertile soils, air and water pollution, destruction of ecosystems, plant and animal poisoning and the potential ingestion and subsequent risk to human health (Abii and Nwosu, 2009; McGuinness and Dowling, 2009). Due to their chemical structure, organic compounds such as petroleum hydrocarbons are resistant to natural breakdown processes and persist for years when released into the environment (McGuinness and Dowling, 2009). Crude oil spillages on land may be due to land disposal of wastes from refineries, leaking oil storage facilities, accidental or criminal damage of pipelines, corrosion of old pipelines and oil tanker accidents (Fine et al., 1997; Abii and Nwosu, 2009; Izinyon and Seghosime, 2013). The presence of crude oil in soil pore spaces causes depletion of oxygen reserves and hinders soil-atmosphere gas exchange (Ayotamuno et al., 2006). Volatilization of light hydrocarbon fractions from contaminated soils releases substantial amounts of potentially carcinogenic compounds which are detrimental to human health. Petroleum hydrocarbon contamination has also been reported to affect plants by retarding seed germination and reducing shoot height, stem density, photosynthetic rate and biomass yield (Lin and Mendelssohn, 1996; Fine et al., 1997).

Conventionally, physicochemical treatment methods such as thermal desorption, incineration, solvent extraction, landfilling, etc. have being employed in the remediation of hydrocarbon-contaminated soils (Jain et al., 2011). However, the high costs and negative environmental impacts of these methods have resulted in heightened interest in exploring the potentials of phytoremediation as a relatively less expensive alternative (Frick et al., 1999; Nedunuri et al., 2000). Phytoremediation involves the use of 
plants and their associated microbes in the extraction, sequestration and degradation of contaminants in aqueous and solid phases. Studies have shown that certain plants have the ability to clean-up several pollutants including metals, pesticides and hydrocarbons (Frick et al., 1999; Nedunuri et al., 2000; Merkl et al., 2005). This remediation method is environmentally friendly, and the soil structure is preserved. It is particularly suited to tropical climates due to the inherent favorable conditions for microbial growth and activity, nutrient availability and biomass production (Merkl et al., 2005). Several plants including tithonian diversifolia, cyperus rotundus, phyllantus amarus, centrosena pubescen, ipomoea batatas, pennisetum pupureum, etc. have been investigated for the remediation of soils contaminated with various petroleum hydrocarbon fractions with findings published in the literature (Ayotamuno et al., 2006; Ogbo et al., 2009; Nwaichi and Onyeike, 2011; Izinyon and Seghosime, 2013; Udo-Inyang et al., 2013; Efe and Elenwo, 2014; Omovbude and Udensi, 2016).

In this study, phytoremediation of crude oil- contaminated soil using locally abundant elephant grass (pennisetum purpureum) was investigated. The specific objectives were to evaluate the phytoremediation capabilities of the plant within the study period and examine the impact on plant growth.

\subsection{Materials and Methods}

\subsection{Collection and preparation of soil samples}

Soil samples and elephant grass used in this study was obtained from a farmland close to the University of Benin, Nigeria. Bonny light crude oil was collected from a company in Port Harcourt, Nigeria. The $\mathrm{pH}$, moisture content, total hydrocarbon content (THC) was determined according to procedures described in Adesodun and Mbagwu, 2008 and Akpe et al., 2015. The $\mathrm{pH}$ of the soil was determined using a $\mathrm{pH}$ meter immersed in soil-water slurry consisting of air-dried and sieved soil mixed at $1 \mathrm{~g} / \mathrm{ml}$ and left to equilibrate for 30 minutes. The moisture content of the soil was determined using the gravimetric method. The soil sample was oven-dried at $105^{\circ} \mathrm{C}$ and the moisture content was calculated as a percentage of the oven-dried weight. THC was determined by hexane extraction. $5 \mathrm{~g}$ of soil was mixed with $23 \mathrm{ml}$ of hexane for 20 minutes and filtered. The absorbance of dilutions of the sample was measured using a spectrophotometer and the concentration of THC was determined based on standard curves for petroleum fractions. The total viable bacterial count and total fungal count were estimated using the standard spread plate technique (APHA, 1992). Serial dilutions of a soil suspension $(1 \mathrm{~g}$ soil $/ 10 \mathrm{ml}$ distilled water) were spread on the surface of nutrient agar and incubated at $35^{\circ} \mathrm{C}$ for 5 days for bacterial isolation and potato dextrose agar incubated at ambient temperature for 7 days for fungal isolation.

\subsection{Experimental Set-up}

Phytoremediation studies were conducted over a 40-day period in four plastic buckets filled with $1 \mathrm{~kg}$ of soil (Figure 1). Two buckets were contaminated with $30 \mathrm{ml}$ and $40 \mathrm{ml}$ of crude oil respectively and treated with elephant grass. Two buckets served as controls (one bucket was contaminated with $30 \mathrm{ml}$ of crude oil with no elephant grass, while the second bucket contained uncontaminated soil with elephant grass). The samples are described in Table 1.

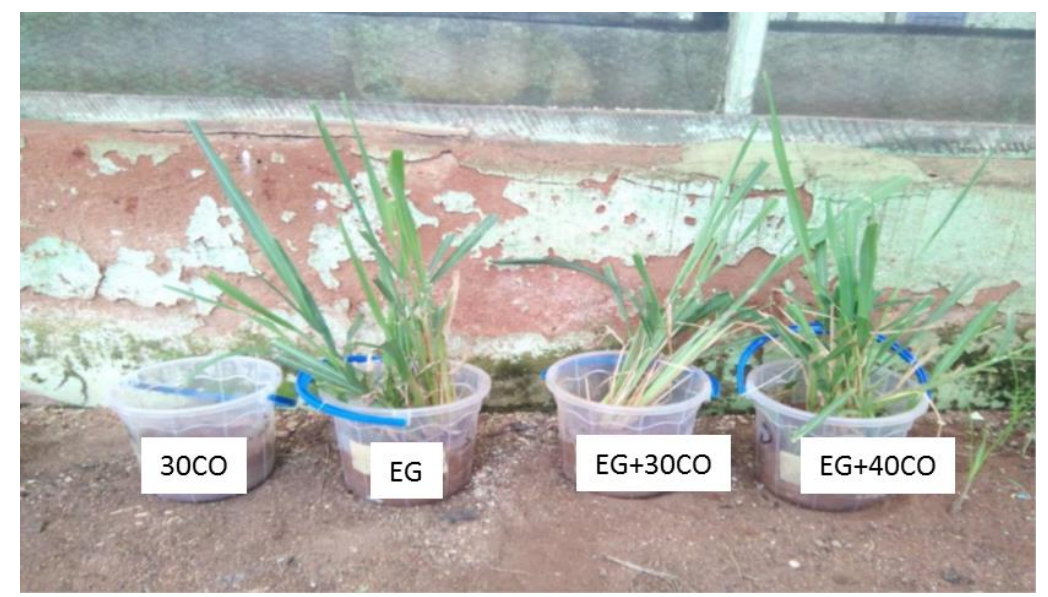

Figure 1: Experimental set-up showing contaminated samples and controls 
Table 1: Description of experimental samples

\begin{tabular}{|l|l|}
\hline Sample & Description \\
\hline EG+30CO & Elephant grass planted in soil contaminated with $30 \mathrm{ml}$ of crude oil \\
\hline EG+40CO & Elephant grass planted in soil contaminated with $40 \mathrm{ml}$ crude oil \\
\hline $30 \mathrm{CO}$ & Control (Unplanted soil contaminated with $30 \mathrm{ml}$ crude oil) \\
\hline EG & Control (Elephant grass planted in uncontaminated soil) \\
\hline
\end{tabular}

The plants were watered daily and soil samples were collected at 10-day intervals for 40 days. The samples were analyzed for changes in $\mathrm{pH}$, total hydrocarbon content, total viable bacterial count and total fungal count. Plant growth was assessed at 5-day intervals by direct measurement using a meter rule.

\subsection{Results and Discussion}

\subsection{Crude oil removal performance}

The analysis of a representative soil sample prior to contamination and treatment revealed that the soil moisture content was $15.4 \%$, $\mathrm{pH}$ was 6.80 , total hydrocarbon content was $<0.001 \mathrm{mg} / \mathrm{kg}$, total viable bacterial count was $188 \mathrm{cfu} / \mathrm{g}$ and the total fungal count was $212 \mathrm{cfu} / \mathrm{g}$.

The residual THC concentrations in the contaminated samples and control were determined as shown in Figure 2 and Table 2. It can be observed that the total hydrocarbon content decreased from 320 to $38 \mathrm{mg} / \mathrm{kg}$ in EG+30CO, 590 to $46 \mathrm{mg} / \mathrm{kg}$ in EG+40CO and 360 to $142 \mathrm{mg} / \mathrm{kg}$ in the contaminated control sample (30CO) after 40 days of treatment. The reduction in THC in the soils undergoing treatment is in agreement with the findings from similar studies (Ayotamuno et al., 2006; Udo-Inyang et al., 2013).

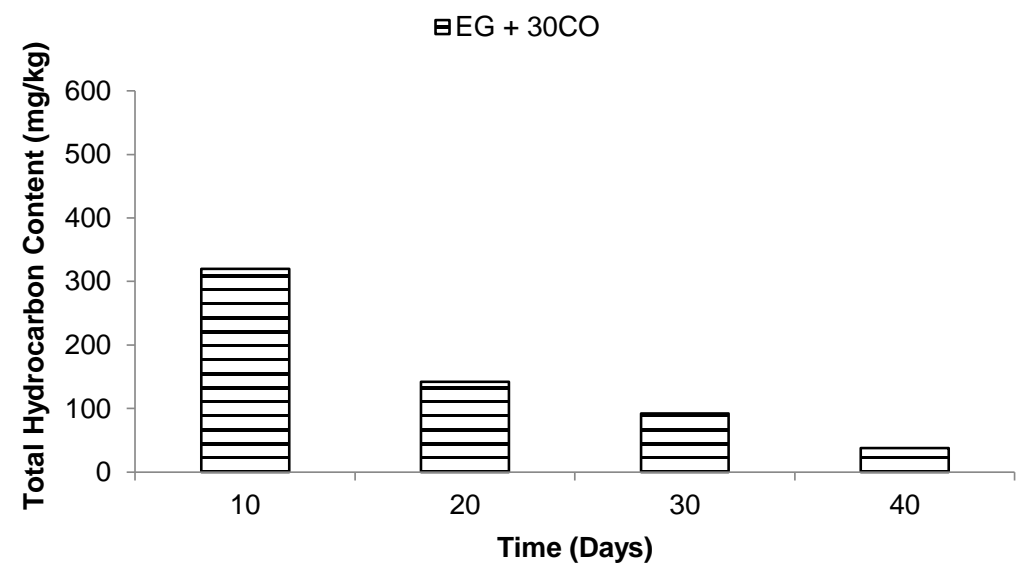

Figure 2a: Reduction in total hydrocarbon content (sample contaminated with $30 \mathrm{ml}$ of crude oil)

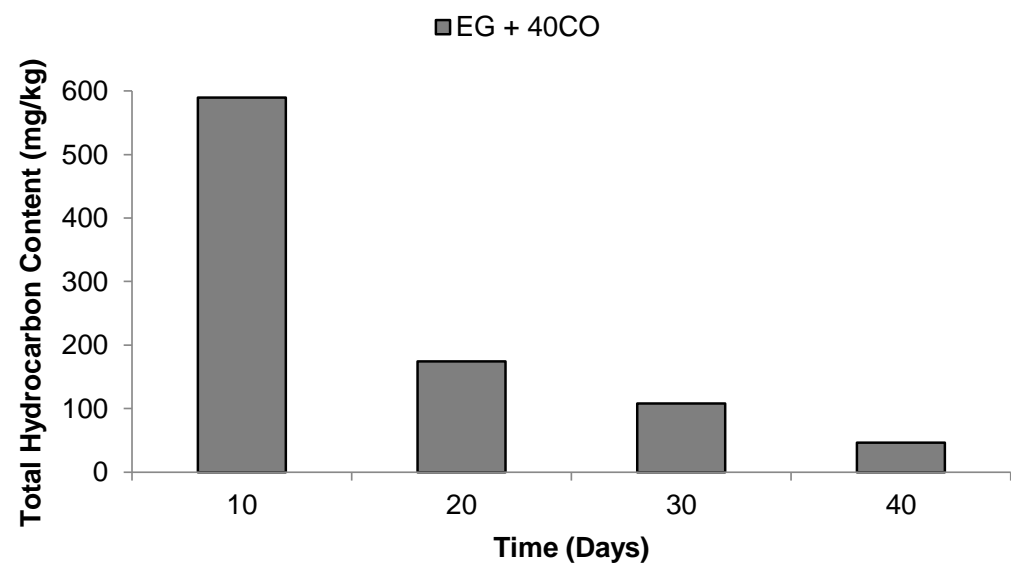

Figure 2b: Reduction in total hydrocarbon content (sample contaminated with $40 \mathrm{ml}$ of crude oil) 

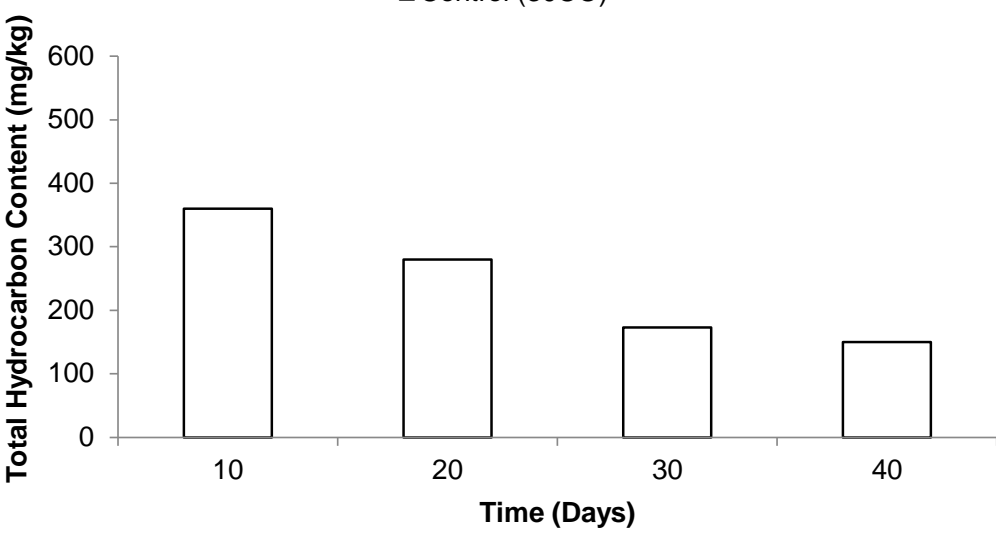

Figure 2c: Reduction in total hydrocarbon content (sample contaminated with 30ml of crude oil)

Phytoremediation of petroleum hydrocarbons may be due to the combined mechanisms of phytodegradation of complex organic molecules taken up by the plant, rhizodegradation involving plant associated bacteria and fungi in the root zone (rhizosphere) and phytovolatilization of the volatile organic fractions (Etim, 2012; Omovbude and Udensi, 2016). The reduction in THC in $30 \mathrm{CO}$ can be attributed to biodegradation by some microbial species present in the soil as reported in other studies (Van Hamme et al., 2003; Akpe et al., 2015). The soil pH ranged from 5.26 to 7.85, with a general decrease observed after 40 days of treatment (Table 2). This suggests the possible presence of sulfur forming minerals which produce acidic conditions on exposure to air or an inherent low buffering capacity (USDA, 1998). The observed increase in microbial counts, particularly in the remediated soil samples indicate the importance of microbial activity and rhizodegradation occurring in the root zone.

Table 2: Characteristics of contaminated soil and control samples

\begin{tabular}{|l|l|l|l|l|}
\hline & EG+30CO & EG+40CO & Control (30CO) & Control (EG) \\
\hline Time (Days) & \multicolumn{5}{|c|}{$\mathrm{pH}$} \\
\hline 10 & 5.93 & 7.11 & 6.90 & 6.53 \\
\hline 20 & 6.88 & 6.80 & 6.82 & 6.71 \\
\hline 30 & 7.30 & 7.14 & 7.05 & 7.65 \\
\hline 40 & 5.80 & 5.80 & 5.53 & 5.26 \\
\hline \multicolumn{5}{|l|}{ Total Hydrocarbon Content (mg/kg) } \\
\hline 10 & 320 & 590 & 360 & $<0.001$ \\
\hline 20 & 142 & 174 & 280 & $<0.001$ \\
\hline 30 & 92 & 108 & 173 & $<0.001$ \\
\hline 40 & 38 & 46 & 142 & $<0.001$ \\
\hline \multicolumn{5}{|c|}{ Total Viable Bacterial Count (cfu/g) } \\
\hline 10 & 168 & 107 & 252 \\
\hline 20 & 192 & 180 & 124 & 274 \\
\hline 30 & 206 & 290 & 352 & 308 \\
\hline 40 & 248 & 432 & 514 & 486 \\
\hline & 414 & 124 & 86 & 234 \\
\hline 10 & 160 & 152 & 106 & 246 \\
\hline 20 & 178 & 258 & 188 & 352 \\
\hline 30 & 232 & 384 & 438 & 410 \\
\hline 40 & 362 & \multicolumn{5}{|l|}{ Total Fungal Count (cfu/g) } \\
\hline
\end{tabular}




\subsection{Impact of crude oil contamination on plant growth}

The growth of plants in contaminated soils and controls was evaluated by direct measurements. The plants grew steadily, with no evidence of inhibition due to crude oil contamination (Figure 3). The average plant heights increased by $33.7 \mathrm{~cm}, 42.8 \mathrm{~cm}$ and $34.5 \mathrm{~cm}$ in EG+30CO, EG+40CO and EG respectively. This resilience suggests the ability of the plant to grow in contaminated environments and the appropriateness of the plant for phytoremediation applications (Wenzel et al., 1999; Izinyon and Seghosime, 2013).

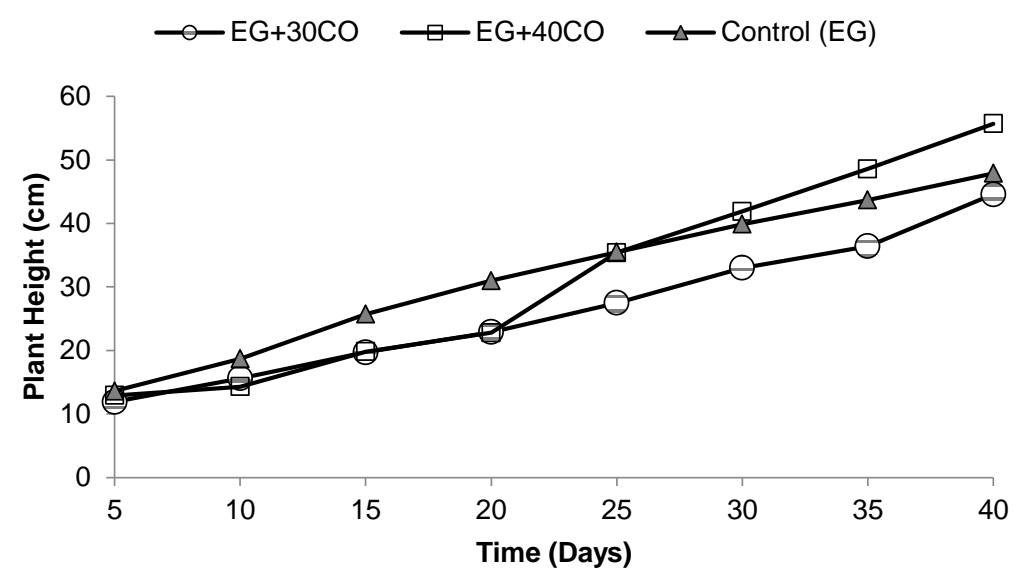

Figure 3: Impact of crude oil contamination on plant height

\subsection{Conclusion}

The phytoremediation capabilities of elephant grass planted in crude oil contaminated soil has been investigated. There was a gradual decrease in the total hydrocarbon content, with $>80 \%$ removal achieved within 40 days in $1 \mathrm{~kg}$ samples contaminated with $30 \mathrm{ml}$ and $40 \mathrm{ml}$ of crude oil. The $\mathrm{pH}$, total viable bacterial count and total fungal count were monitored during the study. The observed increase in total viable bacterial counts and total fungal counts particularly in the treated soil samples may indicate that rhizodegradation involving associated bacteria and fungi in the root zone was a principal removal mechanism. The plants grew steadily with no evidence of inhibition due to crude oil contamination at the levels considered in this study, further confirming their suitability for environmental remediation applications.

\section{References}

Abii, T. A. and Nwosu, P. C. (2009). The effect of oil-spillage on the soil of Eleme in Rivers State of the Niger-Delta area of Nigeria. Research Journal of Environmental Sciences, 3, pp. 316-320.

Adesodun, J. K. and Mbagwu, J. S. C. (2008). Biodegradation of waste lubricating petroleum oil in a tropical alfisol as mediated by animal droppings. Bioresource Technology, 99, pp. 5659-5665.

Akpe, A. R., Esumeh, F. I., Aigere, S. P., Umanu, G. and Obiazi, H. (2015). Efficiency of Plantain Peels and Guinea Corn Shaft for Bioremediation of Crude Oil Polluted Soil. Journal of Microbiology Research, 5(1), pp. 31-40.

APHA 1992. Standard Methods for the Examination of Water and Wastewater, $18^{\text {th }}$ edition, American Public Health Association, Maryland.

Ayotamuno, J. M., Kogbara, R. B. and Egwuenum, P. N. (2006). Comparison of corn and elephant grass in the phytoremediation of a petroleum-hydrocarbon-contaminated agricultural soil in Port Harcourt, Nigeria. Journal of Food Agriculture and Environment, 4(3\&4), pp. 218-222.

Efe, S. I. and Elenwo, E. I. (2014). Phytoremediation of crude oil contaminated soil with Axonopus compressus in the Niger Delta Region of Nigeria. Natural Resources, 5, pp. 59-67. 
Etim, E. E. (2012). Phytoremediation and its mechanisms: a review. International Journal of Environment and Bioenergy, 2(3), pp. 120-136.

Fine, P., Graber, E. R. and Yaron, B. (1997). Soil interactions with petroleum hydrocarbons: Abiotic processes. Soil Technology, 10(2), pp. 133-153.

Frick, C. M., Farrel, R. E. and Gemida, J. J. (1999). Assessment of phytoremediation as an in-situ technique for cleaning oil contaminated sites. Petroleum Technology Alliance Canada, Calgary.

Izinyon, O. C. and Seghosime, A. (2013). Assessment of sweet potato (Ipomoea batatas) for phytoremediation of motor oil contaminated soil. Nigerian Journal of Technology, 32(3), pp. 371-378.

Jain, P. K., Gupta, V. K., Gaur, R. K., Lowry, M., Jaroli, D. P. and Chauhan, U. K. (2011). Bioremediation of petroleum oil contaminated soil and water. Research Journal of Environmental Toxicology, 5, pp. 1-26.

Lin, Q. and Mendelssohn, I. A. (1996). A comparative investigation of the effects of south Louisiana crude oil on the vegetation of fresh, brackish and salt marshes. Marine Pollution Bulletin, 32(2), pp. 202-209.

McGuinness, M. and Dowling, D. (2009). Plant associated bacteria degradation of toxic organic compounds in soils. International Journal of Environmental Research and public Health, 6(8), pp. 2226-2235.

Merkl, N., Rainer, S. K., and Marianela, A. (2005). Effect of the tropical grass Brachiaria brizantha on microbial population and activity in petroleum-contaminated soil. International Journal of Phytoremediation, 7(3), pp. 217-30.

Nedunuri, K.V., Govindaraju, R.S., Banks, M.K., Schwab A. P. and Chen, Z. (2000) Evaluation of phytoremediation for field-scale degradation of total petroleum hydrocarbons. ASCE Journal of Environmental Engineering, 126(6), pp.483-490

Nwaichi, E. O. and Onyeike, E. N. (2011). Interaction of selected minerals with organic pollutants: effects of phyto-assisted bioremediation using Vigna subterranean. Journal of Environmental and Analytical Toxicology, 1(2), pp. 1-4.

Ogbo, E. M., Avwerosowe, U. and Odogu, G. (2009). Screening of four common Nigerian weeds for use in phytoremediation of some soil contaminated with lubricating oil. African journal of Plant Science, 3, pp. 102-106.

Omovbude, S. and Udensi, U. E. (2016). Review of weeds with phytoremediation potentials of petroleum contaminated soil in the Niger-Delta state. Nature and Science, 14(11), pp. 47-55.

Udo-Inyang, U. C., Edem, I. and Nkereuwem, J. M. (2013). Application of phyto-remediation (sunflower and vetiver grass) on crude oil spilled soil cultivated to jute mallow (Corchorus olitorius L.). Resources and Environment, 3(6), pp. 169-175.

Ugochukwu, C. N. C. and Ertel, J. (2008). Negative impacts of oil exploration on bio-diversity management in the Niger-Delta area of Nigeria. Impact Assessment and Project Appraisal, 26(2), pp. $139-147$.

USDA (1998) Soil Quality Indicators: pH, United States Department of Agriculture, Washington D.C.

Van Hamme, J. D., Singh, A. and Ward, O.P. (2003). Recent advances in petroleum microbiology. Microbiology and Molecular Biology Reviews, 67(4), pp. 503-549. 
Wenzel, W. W., Adriano, D. C., Salt, D. and Smith, R. (1999). Phytoremediation: A plant - microbe based Remediation system, pp. 457-508 In: Bioremediation of Contaminated Soils, edited by D.C. Adriano, J. M., Bollag, W. T. Frankenberger Jr. and R. C. Sims. Madison, W. I. 